героїв, відбувається усвідомлення причин і наслідків заплутаного конфлікту у фіналі твору, що призводить до його вирішення. Нил Микитович досягає вищого рівня свідомості у результаті осмислення усієї конфліктної ситуації, сформованої діями та бездіяльністю дорослих, що призводить до знімання напруги в міжособистісних та суспільних взаємодіях.

\title{
Література:
}

1. Адорно Т. Теорія естетики / пер. 3 нім. П. Таращук. К.: Видавництво Соломії Павличко «Основи», 2002. 518 с.

2. Гачев Г. Д. Содержательность художественных форм. Эпос. Лирика. Театр. Москва: Просвещение, 1968. 302 с.

3. Клековкін О. Ю. Theatrica. Морфологія: лексикон. К.: Арт Економі, 2011. 444 с.

DOI https://doi.org/10.30525/978-9934-26-073-5-1-23

\section{ХУДОЖНС ОСМИСЛЕННЯ ТА ТЛУМАЧЕННЯ КАТЕГОРІЇ ЧАСУ ТА ПРОСТОРУ У ЛІРИЦІ Є. ПЛУЖНИКА}

\author{
Білічак О. I. \\ кандидат філологічних наук, \\ викладач кафедри мовознавства, \\ Івано-Франківського начіонального медичного університету \\ м. Івано-Франківськ, Украӥна
}

Художнього осмислення і тлумачення набувають у ліриці Є. Плужника філософські категорії часу та простору. В. Халізєв виділяє образи часу біологічного (дитинство, юність, зрілість, старість), історичного (характеристики зміни епох і поколінь, великих подій у житті суспільства), космічного (уявлення про вічність та вселенську історію), календарного (зміна пір року, буднів та свят), добового (день і ніч, ранок i вечір), а також уявлення про рух і нерухомість, про співвідношення минулого, теперішнього, майбутнього [1, с. 26]. Останню із названих категорій можна окреслити як час екзистенційний.

Для ліричного героя сьогодення не сприймається крізь призму історичного минулого, яке у своєму трагізмі сягнуло героїчних висот. Герой живе у часі, яке не $\epsilon$ ідеальним продовженням громадянських поступів минулого, він розчарований реальною дійсністю, однак його 94 
дні, на думку М. Кодака, - «це реалія 3 історико-психологічним наповненням, реалія, ідейно-емоційна змістовність якої орудно добувається кожною «сапкою», кожною душею майбутніх поколінь. Дні майбутні постануть святами тільки в єдності 3 буднями, тільки в діалектичній сув'язі нової духовності з духовністю днів минулих» [2, с. 39]. Ліричний герой Є. Плужника відчуває духовну розірваність свого покоління 3 природою, відтак 3 попередніми епохами і часом. Сьогодення постає як безідейний пошук сенсу буття, а отже - віри в «світле майбутнє» не існує: «Одірвались від днів слова, / В’януть собі по книжках, а у днях - / мов у темному лісі!» [3, с. 141]. Однак це тільки видається на перший погляд. У відчайдушному звертанні констатується життєва істина: «Брешете ви, кому ясне усе! / Перед мрією усі ми ниці» [3, с. 141]. Адже лише щирі і відкриті почуття наближають людину до осягнення Всесвіту, лише людині не треба зневірятися. Часопростір Є. Плужника включає взаємодію минулого із майбутнім, саме така позиція є підтвердженням думки М. Кодака, що «минуле повіряється майбутнім, буває, навіть кількаразово; часто реалії твору полишаються відкритими для майбутнього, ніби «в розбігу» в новий час» [2, с. 35].

Майбутнє у візіях поета постає у різних іпостасях, залежно від настрою поетичного слова. Поет то впадає у власні спостереження «я» у майбутніх перспективах: «Воскресінням твоїм живу, Земле мертва! [3, с. 141], «Мета моя далека, / Я такої смерті не боюсь! / Зійде кров, немов всесвітня Мекка» [3, с. 126], то пророкує духовну деградацію суспільства: «А тепер там зійшов полин. / Телеграфні стовпи...» [3, с. 132]. Все це приводить його філософські інтенції у напрям усвідомлення проблем, пов'язаних із відродженням гуманізму i людяності, а звідси йде наближення до неокласичних постулатів із спробою відновлення класицистичних ідей, пов'язаних із поняттями Краси, Ідеалу, лише у парадоксально новому сенсі - через мистецький показ категорій антигуманності сучасного світу: страху, страждань, болю i розчарувань. Тому рядки його поезій сприймаються скоріше як афористичні висловлювання: «Мовчки зросте десь новий Тарас / Серед кривавих піль!» [3, с. 124], «Умій в нудьзі знаходити розраду» [3, с. 124], «Краще помилятися самому, / Ніж чужих навчившись помилок!» [3, с. 239]. Ними письменник звертається не стільки до сучасників, скільки хоче навернути читача майбутнього до усвідомлення причин трагедії сучасного для поета суспільства, у якому цілком відсутній $\epsilon$ зв'язок із минулими подіями, пов'язаними з громадянською війною i героїкою минулого суспільства. 
У зображенні подій і наслідків минулої для нього громадянської війни він категоричний, адже це трагедії суспільства і трагедія кожної конкретної людини, яка стала жертвою тих подій: «А хто з них винний, а хто з них правий! - 3-під однакових стріх!» [3, с. 127]. У поезіях «Був це хлопець лагідний і тихий», «Мабуть дуже йому боліло», «Ще в полон не брали тоді», «Уночі його вели на розстріл» та ін. в експресіоністичному ключі Є. Плужник відображає ситуацію, коли у минулому зникають імена як героїв, так і ворогів, всі стають однаковими, і тим самим підкреслюється думка, яка відображає так званий «новий» закон суспільства, коли один герой вмирає, то це стає трагедією, а коли смертей стає забагато, то це стає статистичною інформацією. Підтверджує таку позицію й думка Л. Череватенка, який висловлює власні міркування з приводу відображення подій громадянської війни у ліриці Є. Плужника: «Це насамперед війна самогубча: син проти батька, батько проти сина. Що заховують оці вірші? Великий біль. Великий жаль: що не впізнали один одного, що не порозумілися, не навчилися одне одного шанувати» $[4$, с. 40$]$. А звідси виникає проблема - наступне спадкоємне покоління може не стати прямим продовженням життя, адже несвідомо може загинути у «гирлі» братовбивчої i покоління знищувальної війни, а в цьому не лише родинна трагедія, а насамперед трагедія національна, що призводить до ії смерті.

Художнє тлумачення простору конденсоване, згущене. Значеннєве наповнення домінанти характеризується антитетичністю («безмір...невеличкий») як принципом світосприйняття митця» [1, с. 31].

Концептуальне значення в художньому світі $Є$. Плужника має образ вікна. Емотивне тло домінанти характеризується поліаспектністю прочитань. Так, вікно $є$ способом споглядання світу із замкненого простору кімнати. Ця категорія стає першопочатком всього сущого у всіх просторових вимірах:

«Мовчіть, умріяні сторінки!

- Я справжнім болем догорів!

I знов за вікнами будинки

І мертве світло ліхтарів...» [3, с. 148].

«Зорове сприймання зображуваного поглиблюється емоційністю фрази (риторичні звертання та оклики). Митець апелює до асоціативності, образно втілюючи художню проекцію власного світу. Погляд «за вікно» визначається зміною емоційного наповнення. Поле нашого зору спрямоване на конкретні реалії життя людини («будинки», «ліхтарі»). Образ вікна виступає тлом для функціонування поетичної 
уяви як прояв іншої, тіньової сторони людської свідомості, як опозиція світу реального з його звичними уявленнями та нормами.

Згодом, простір «за вікном» переводить світ вірша із реального плану в ірреальний. Тобто здійснюється вихід за межі конкретного матеріального світу - у світ тишини: «Що, коли підійду серед ночі / До знайомого добре вікна, / Бачать болем засмучені очі / Тишину до останнього дна!» [3, с. 183]. Ліричний герой сягає внутрішнім зором «дна тишини». Симптоматично, що для споглядання світу i себе у ньому митець обирає ту частину доби, коли найчутнішим є будь-який звук ніч. Вікно є маркером світо- і самозаглиблення. Поезія обернена до глибини буття і позначена настроєм містичності. Побачити «дно тишини» можливо лише «болем засмученими очима», переосмисливши власне життя, своє місце в ньому. Образ вікна більш місткий, потужніший, це зумовлюється додатковим семантичним навантаженням» [1, с. 31].

Висновок. Філософського звучання і осмислення у поезії С. Плужника набувають категорії часу та простору. Щодо часу, то він у майстра поетичного слова виступає у ракурсі історичного та особистісного, із переважанням останнього. У поезії митець прагне до осягнення таємниць часу. При чому історичний час для нього - страшний i жорстокий, людина має виживати у ньому задля збереження особистісного часу, болісно переживати цей період бездуховності i жорстокості. Біографічний, або особистісний час у поезіях стає художньою проекцією авторського світу митця і усвідомлюється на фоні «безміру світового». Особистісний час у поезії охоплює три напрями інтерпретації: власне час, частини доби (добовий час), календарний час.

\section{Література:}

1. Білічак О. Часопросторова модель художнього світу поезії митця. Науковий журнал Львівського державного університету безпеки життєдіяльності «Львівський філологічний часопис»; Збірник наукових праць. Львів, 2018. Вип3. С. 26-31.

2. Кодак М. Огром Свгена Плужника - поета: монографія; НАН Украӥни, Ін-т літ. ім. Т. Шевченка. Луцььк: Твердиня, 2009. 189 с.

3. Плужник Є. Поезії. Укл., вступна стаття і прим. Л. В. Череватенка. К.: Рад. письменник, 1988. 415 с.

4. Череватенко Л. Все, чим душа боліла. Плужник Є. Поезї. К.: Радянський письменник, 1988. С. 5-100. 